\title{
PULMONARY FUNCTION IMPAIRMENT AND AIRWAY ALLERGY AMONG WORKERS IN TRADITIONAL BAKERIES
}

\section{AYMAN EKRAM FAHIM ${ }^{1}$ and MAHMOUD EL-PRINCE ${ }^{2}$}

\author{
${ }^{1}$ Suez Canal University, Ismailia, Egypt \\ Department of Community Medicine \\ ${ }^{2}$ Suez Canal University, Ismailia, Egypt \\ Pumonary Medicine Unit, Faculty of Medicine
}

\begin{abstract}
Objectives: To assess the effect of exposure to flour dust on pulmonary function tests, prevalence of symptoms (respiratory, allergic/irritating) and parameters of allergic sensitization in terms of skin prick test, and bronchial hyper-responsiveness. Material and Methods: 43 bakers (with at least 2 years of occupational exposure) working at different bakeries in Ismailia city, Egypt; and 64 control subjects of comparable socio demographic characteristics were compared. All participants were subjected to an interview questionnaire, clinical chest examination, skin prick test, bronchial hyper-responsiveness test and measurements of pulmonary function parameters. Results: All respiratory and allergic symptoms were more prevalent among bakers compared to the control group, with the highest odds ratio for allergic symptoms $(\mathrm{OR}=6.9 ; \mathrm{p}<0.0001)$ and dyspnea $(\mathrm{OR}=6.3 ; \mathrm{p}=0.0004)$. Bakers had a higher percentage of SPT positive results with statistically significant difference between the two groups $(\mathrm{p}<0.0001)$. Bakers had lower observed values compared to the control group with statistically significant difference for $\mathrm{FVC}, \mathrm{FEV}_{1} / \mathrm{FVC}$ ratio, $\mathrm{FEF}_{75 \%}$, and $\mathrm{FEF}_{25-75 \%}$ parameters. Conclusion: The present study suggested that occupational exposure to flour dust may affect respiratory irritation and sensitization, and reduce the pulmonary function tests such as $\mathrm{FVC}, \mathrm{FEV}_{1}$, and $\mathrm{FEV}_{1} / \mathrm{FVC}$ ratio and $\mathrm{FEF}_{25-75 \%}$.
\end{abstract}

Key words:

Pulmonary function, Allergic sensitization, Bakers

\section{INTRODUCTION}

Flour dust is a hazardous substance; it is a respiratory sensitizer which is known to cause allergic rhinitis and occupational asthma. It is estimated that 10 to $25 \%$ of all adult - onset asthma cases are occupationally related. Among these, baker's asthma is one of the most frequent types of occupational asthma [1].

Bakers are continuously exposed to flour dust in their workplaces. Flour dust is defined as finely ground particles of cereal or pulses along with other contaminants, which are released during grinding processes and subsequent handling and use of that flour [1]. In the last 20 years, wheat flour (Triticum aestivum) and other cereal flours (Secale cereale, Hordeum vulgare) have been reported as principal allergens for bakers' allergy and asthma [2-4]. Flour dust is also an irritant which induces respiratory, nasal and eye symptoms. It may provoke an asthmatic attack in individuals with pre-existing disease and lead to

Received: March 15, 2012. Accepted: September 5, 2012.

Corresponding author: A.E. Fahim, Department of Community Medicine, Occupational Health Group, Faculty of Medicine, Suez Canal University, Ismailia 41522, Egypt (e-mail: afahim70@gmail.com). 
chronic bronchitis [5]. Some investigators have reported normal pulmonary function whereas others observed abnormal lung volumes in the workers exposed to flour dust. Although there are numerous studies on occupational allergens, there is still little information available regarding the epidemiology of allergic sensitization in baking industry $[1,6]$.

This study was conducted to assess the effect of exposure to flour dust on pulmonary function parameters, and other parameters of allergic sensitization in terms of skin prick test, and bronchial hyper-responsiveness.

\section{MATERIAL AND METHODS}

During 2010/2011 and in a period of 11 months of work, a cross-sectional study was conducted among bakers (exposed group) at different traditional bakeries in Ismailia city, Egypt. A control group (not exposed to flour dust) was selected from workers at the adjacent grocery stores in the same area. The studied subjects were all males of comparable age and other socio-demographic characteristics. 43 bakers (with at least 2 years of occupational exposure), and 64 control subjects participated in the study. The bakers worked 8-10 hours per day; they did not use any personal protective equipment and they worked in poorly ventilated workplaces (traditional bakeries) exposing them to heavy flour dust exposure. Those with chronic medical disorders (hypertension - diabetes mellitus) or previous history of surgical operations were excluded.

A written consent was taken from each participant before introducing the questionnaire; confidentiality and anonymity were maintained according to the regulations mandated by Research Ethics Committee of faculty of Medicine, Suez Canal University, in accordance with the Declaration of Helsinki.
All participants of the study were subjected to a clinical chest examination (mainly wheezes), skin prick test, bronchial hyper-responsiveness test and pulmonary function parameters.

The interview questionnaire contained items concerning personal history, history of atopy, smoking status, occupational characteristics and respiratory (cough, dyspnea, phlegm) and allergic/irritation symptoms of the eye, nose and skin. The questionnaire was based on the items domains of the Medical Research Council (MRC) [7].

Local examinations of the chest (auscultation) were done by an experienced pulmonologist. Pulmonary function measurements were taken using spirometry Flowhandy ZAN100 USB (ZAN Messgerate GmbH, Germany) and included Forced Vital Capacity (FVC), Forced Expiratory Volume at 1 second $\left(\mathrm{FEV}_{1}\right),\left(\mathrm{FEV}_{1} / \mathrm{FVC}\right.$ ratio), Forced Expiratory Flow 50\% $\left(\mathrm{FEF}_{50 \%}\right)$, Forced Expiratory Flow $75 \%\left(\mathrm{FEF}_{75 \%}\right)$, and Forced Expiratory Flow $25 \%$ to $75 \%\left(\mathrm{FEF}_{25-75 \%}\right)$. All pulmonary function tests were carried out and the best of the three measurements was recorded (observed values), according to the American Thoracic Society (ATS) recommendations [8].

Skin prick testing (SPT) to three common inhalant aeroallergens was performed on the volar aspect of the forearm using allergen extracts of aspergillus fumigatus, wheat flour and house dust mite. All tests included positive $\left(1 \mathrm{mg} \times \mathrm{ml}^{-1}\right.$ histamine) and negative ( $0.9 \%$ saline) controls. Prick tests were considered positive if the mean wheal diameter $20 \mathrm{~min}$ after allergen application was at least $3 \mathrm{~mm}$ larger than the size of the negative control $[9,10]$.

Bronchial hyper-responsiveness was investigated using histamine challenge in accordance with the American Thoracic Society (ATS) recommendations. Different

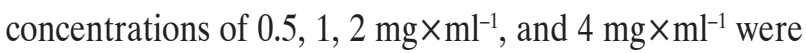
prepared by dilution with buffered saline. The subjects inhaled increasing concentrations of histamine using a tidal breathing method until $\mathrm{FEV}_{1}$ fell by more than $20 \%$ of its base value or the highest concentration was reached. 
The statistical analysis was performed using Sigma Stat version 3.5. The data was analyzed using Chi-square test (qualitative data); and Student t-test (quantitative data). Odds ratio was estimated between groups with $95 \%$ confidence interval (CI) for symptoms and other variables. Results were considered statistically significant if $p$ value $<0.05$ and two-sided testing was used for statistical inference.

\section{RESULTS}

Both studied groups were similar as regards the different socio-demographic characteristics as presented in (Table 1). Current smokers among bakers represented $48.8 \%$ of the group and $39.1 \%$ in the control group with no statistically significant difference between the two groups.

As shown in Table 2, all respiratory and allergic symptoms were more prevalent among bakers compared to the control group, and the differences were statistically significant with the highest odds ratio for allergic symptoms $(\mathrm{OR}=6.9 ; \mathrm{p}<0.0001)$ and dyspnea $(\mathrm{OR}=6.3$; $\mathrm{p}=0.0004)$. Among bakers, $48.8 \%$ were smokers compared to the control group (39.1\%), the result was not statistically significant $(\mathrm{p}>0.05)$.

Bakers had more positive results of SPT with statistically significant difference between the two groups $(\mathrm{p}<0.0001$; $\mathrm{OR}=14.3$ ). Among the different allergens tested, wheat

Table 1. Characteristics of bakers and control groups

\begin{tabular}{lrrrrr}
\hline \multirow{2}{*}{\multicolumn{1}{c}{ Characteristics }} & \multicolumn{2}{c}{$\begin{array}{c}\text { Bakers group } \\
(\mathrm{N}=43)\end{array}$} & \multicolumn{2}{c}{$\begin{array}{c}\text { Control group } \\
(\mathrm{N}=64)\end{array}$} & \multirow{2}{*}{ p-value } \\
\cline { 2 - 5 } & $\mathrm{M}$ & $\mathrm{SD}$ & $\mathrm{M}$ & $\mathrm{SD}$ & \\
\hline Age (years) & 34.7 & 13.3 & 37.4 & 10.4 & 0.242 \\
Height $(\mathrm{cm})$ & 168.3 & 2.7 & 167.7 & 3.2 & 0.314 \\
Weight (kg) & 72.6 & 3.9 & 73.9 & 3.4 & 0.071 \\
Body Mass Index & 26.3 & 1.8 & 27.2 & 2.7 & 0.058 \\
Current work duration (years) & 10.7 & 6.3 & 10.9 & 5.7 & 0.865 \\
Smoking (current) (n (\%)) & 21.0 & $(48.8)$ & 25.0 & $(39.1)$ & $0.316^{*}$ \\
\hline
\end{tabular}

M - mean; SD - standard deviation.

* p-value based on Chi-square test.

Table 2. Respiratory symptoms and clinical findings among the studied groups

\begin{tabular}{|c|c|c|c|c|c|c|c|}
\hline \multirow[t]{2}{*}{ Characteristics } & \multicolumn{2}{|c|}{$\begin{array}{l}\text { Bakers group } \\
\quad(\mathrm{N}=43)\end{array}$} & \multicolumn{2}{|c|}{$\begin{array}{c}\text { Control group } \\
(\mathrm{N}=64)\end{array}$} & \multirow[t]{2}{*}{ OR } & \multirow[t]{2}{*}{$95 \% \mathrm{CI}$} & \multirow[t]{2}{*}{ p-value } \\
\hline & $\mathrm{n}$ & $\%$ & $\mathrm{n}$ & $\%$ & & & \\
\hline$\overline{\text { Cough }}$ & 31 & 72.1 & 25 & 39.1 & 4.1 & $1.7-9.3$ & 0.0008 \\
\hline Phlegm & 29 & 67.4 & 20 & 31.3 & 4.5 & $1.9-10.4$ & $0.0002^{*}$ \\
\hline Dyspnea & 15 & 34.9 & 5 & 7.8 & 6.3 & $2.1-19.2$ & $0.0004 *$ \\
\hline Clinical findings (wheeze) & 14 & 32.6 & 7 & 10.9 & 3.9 & $1.4-10.8$ & $0.0005^{*}$ \\
\hline $\begin{array}{l}\text { Allergy/Irritation symptoms } \\
\text { (nasal-eye-skin) }\end{array}$ & 18 & 41.9 & 6 & 9.4 & 6.9 & 2.4-19.6 & $<0.0001$ \\
\hline
\end{tabular}

OR - odds ratio; $\mathrm{CI}$ - confidence interval.

* Statistically significant at $\mathrm{p}<0.05$. 
Table 3. Comparison of the prevalence of positive skin prick test (SPT) and bronchial hyper-responsiveness (BHR) between bakers and the controls

\begin{tabular}{lrrrrrrc}
\hline \multirow{2}{*}{ Characteristics } & \multicolumn{2}{c}{$\begin{array}{c}\text { Bakers group } \\
(\mathrm{N}=43)\end{array}$} & \multicolumn{2}{c}{$\begin{array}{c}\text { Control group } \\
(\mathrm{N}=64)\end{array}$} & OR & 95\% CI & p-value \\
\cline { 2 - 5 } & $\mathrm{n}$ & $\%$ & $\mathrm{n}$ & $\%$ & & & \\
\hline SPT & 21 & 48.8 & 4 & 6.3 & 14.3 & $4.4-46.4$ & $<0.0001^{*}$ \\
Aspergillus fumigatus & 5 & 11.6 & 2 & 3.1 & - & - & $0.018^{*}$ \\
wheat flour & 12 & 27.9 & 1 & 1.6 & - & - & $<0.0001^{*}$ \\
house dust mite & 4 & 9.3 & 1 & 1.6 & - & - & 0.062 \\
BHR & 11 & 25.6 & 7 & 10.9 & 2.7 & $0.89-7.9$ & $0.085^{* *}$ \\
\hline
\end{tabular}

Abbreviations as in Table 2.

* Statistically significant at $\mathrm{p}<0.05$.

** p-value based on Chi-square test with Yates' correction.

Table 4. Comparison of different pulmonary function parameters among the studied bakers and the control group

\begin{tabular}{|c|c|c|c|c|c|}
\hline \multirow{2}{*}{$\begin{array}{l}\text { Pulmonary } \\
\text { parameters }\end{array}$} & \multicolumn{2}{|c|}{$\begin{array}{l}\text { Bakers group } \\
\quad(\mathrm{N}=43)\end{array}$} & \multicolumn{2}{|c|}{$\begin{array}{l}\text { Control group } \\
(\mathrm{N}=64)\end{array}$} & \multirow[t]{2}{*}{ p-value } \\
\hline & $\mathrm{M}$ & $\mathrm{SD}$ & $\mathrm{M}$ & SD & \\
\hline $\mathrm{FVC}$ & 3.8 & 0.7 & 4.4 & 0.6 & $0.002 *$ \\
\hline $\mathrm{FEV}_{1}$ & 3.4 & 0.8 & 3.6 & 0.5 & 0.114 \\
\hline $\mathrm{FEV}_{1} / \mathrm{FVC}$ & 87.1 & 6.8 & 91.2 & 7.1 & $0.004 *$ \\
\hline $\mathrm{FEF}_{50 \%}$ & 4.7 & 1.2 & 5.1 & 1.4 & 0.128 \\
\hline $\mathrm{FEF}_{75 \%}$ & 2.7 & 0.9 & 3.1 & 0.8 & $0.018^{*}$ \\
\hline $\mathrm{FEF}_{25-75 \%}$ & 7.2 & 2.1 & 8.6 & 1.9 & $<0.001^{*}$ \\
\hline
\end{tabular}

Abbreviations as in Table 1.

* Statistically significant at $\mathrm{p}<0.05$.

flour had the highest percentage among bakers $(27.9 \%)$ as presented in Table 3.

Bakers had lower observed values for FVC, $\mathrm{FEV}_{1}, \mathrm{FEV}_{1} /$ FVC ratio, $\mathrm{FEF}_{50 \%}, \mathrm{FEF}_{75 \%}$, and $\mathrm{FEF}_{25-75 \%}$ compared to the control group with statistically significant difference for $\mathrm{FVC}, \mathrm{FEV}_{1} / \mathrm{FVC}$ ratio, $\mathrm{FEF}_{75 \%}$, and $\mathrm{FEF}_{25-75 \%}$ as presented in Table 4.

\section{DISSCUSION}

Although there are numerous studies on occupational allergens, there is still little information available regarding the epidemiology of allergic sensitization in the flour industry [12].
In the present study, all respiratory and allergic symptoms were more prevalent among bakers compared to the control group and the differences were statistically significant. This is in compliance with many studies carried out on bakers [13,14]. In addition, bakers have been reported to exhibit a variety of clinical manifestations, including conjunctivitis, allergic and baker's asthma, wheezing, febrile reactions, grain fever, lung fibrosis, rhinitis, allergic alveolitis, impairment of lung function, and chronic obstructive pulmonary disease [4].

Gimenez et al. (1995) [15] have observed that flour dust exposure causes cough, sputum production and the decreased pulmonary function values among bakers compared to their 
matched controls. Moreover, Bohadana et al. (1994) [16] showed that regardless of exposure to relatively low concentration levels of respirable flour dust, subjects working in baking industry are at risk of developing respiratory symptoms and airway hyper-responsiveness. Concerning the present study, the higher prevalence of respiratory symptoms, as well as eye and nasal allergic symptoms may be explained by relatively prolonged exposure, poor hygienic conditions and poorly ventilated workplaces where the study was carried out [17]. Positive SPT to wheat grain was more prevalent among bakers compared to the control group with statistically significant difference. This is in accordance with many authors, who reported that the principal sensitizer in bread bakeries is wheat flour dust [2,3,18-22].

Bakers had lower observed values of $\mathrm{FVC}, \mathrm{FEV}_{1} / \mathrm{FVC}$ ratio, $\mathrm{FEF}_{75 \%}$, and $\mathrm{FEF}_{25-75 \%}$ parameters in comparison with the control group. Several studies have reported similar reductions among bakers when compared with control groups [1,23-26].

Shamssain (1995) [27] investigated pulmonary function parameters in non-smoking bakery workers and reported that the exposed group had lower forced expiratory indices than the control group. Shamssain also found that the predicted values of $\mathrm{FEV}_{1}, \mathrm{FEV}_{1} / \mathrm{FVC}, \mathrm{FEF}_{25-75 \%}$, and PEFR were respectively, 11.2, 20.0, 31.0, and by $36.1 \%$ lower in the exposed group compared to the controls. Chen [28] categorized exposed bakers into high and low exposure groups and found that $\mathrm{FEV}_{1}, \mathrm{FVC}, \mathrm{MEF}$ and PEF were decreased in the highly exposed group. The findings indicated that chronic exposure to high concentrations of flour dust impaired the pulmonary function indices.

The present study confirmed the results of other studies and suggested that occupational exposure to flour dust may cause or affect respiratory irritation and sensitization; and reduce the pulmonary function tests such as FVC, FEV and $\mathrm{FEV}_{1} / \mathrm{FVC}$ and $\mathrm{FEF}_{25-75 \%}$. These findings mandate to pre-employment and periodic spirometry and SPT examination for bakers. Proper ventilation, workplace hygiene, protective personal equipment and health education programs should be carried out to promote and protect the workers' health.

\section{REFERENCES}

1. Meo SA, Al-Drees AM. Lung function among non-smoking wheat flour mill workers. Int J Occup Med Environ Health 2005;18:259-64.

2. Burstyn I, Teschke K, Bartlett K, Kennedy SM. Determinants of wheat antigen and fungal alpha-amylase exposure in bakeries. Am Ind Hyg Assoc J 1998;59:313-20.

3. Pavlovic M, Spasojevic M, Tasic Z, Tacevic S. Bronchial hyperactivity in bakers and its relation to atopy and skin reactivity. Sci Total Environ 2001;270:71-5.

4. Dosman JA, Graham BL, Cotton DJ. Chronic bronchitis and exposure to cereal grain dust. Am Rev Respir Dis 1979;120:477-80.

5. Anton M, Bataille A, Mollat F, Bobe M, Bonneau C, Caramaniam MN, et al. Respiratory allergies among bakers and pastry cooks: epidemiologic survey done in 1991 by the occupational physicians of the Loire-Atlantique [in French]. Allerg Immunol (Paris) 1995;27:12-5.

6. Bulat P, Myny K, Braeckman L, Van Sprundel M. Exposure to inhalable dust, wheat flour and $\alpha$-amylase allergens in industrial and traditional bakeries. Ann Occup Hyg 2004;48:57-63.

7. Medical Research Council Committee on the Etiology of Chronic Bronchitis. Standardized Questionnaire on respiratory symptoms. Br Med J 1960;ii:1665.

8. American Thoracic Society. Statement on standardization of spirometry. Am Rev Respir Dis 1987;136:1286-96.

9. Herxheimer H. The skin sensitivity to flour of bakers' apprentices. Acta Allergol 1973;28:42-9.

10. Cullinan P, Cook A, Nieuwenhuijsen MJ, Sandiford C, Tee RD, Venableset KM, et al. Allergen and Dust Exposure as Determinants of Work-Related Symptoms and Sensitization in a Cohort of Flour-Exposed Workers; A Case-control Analysis. Ann Occup Hyg 2001;45:97-103. 
11. American Thoracic Society. Guidelines for metacholine and exercise challenge testing - 1999. Am Respir Crit Care Med 2000;161:309-29.

12. Alcalde JM, Alonso AS, Alonso AP. Allergic disorders in cookie factory: preliminary results of a cross-sectional prevalence study. Allergol Immunol Clin 2000;15:83-7.

13. Cullinan P, Lowson D, Nieuwenhuijsen MJ, Sandiford C, Tee RD, Venables KM, et al. Work-related symptoms, sensitisation, and estimated exposure in workers not previously exposed to flour. Occup Environ Med 1994;51:579-83.

14. Houba R, Heederik D, Doekes G. Wheat sensitization and work related symptoms in the baking industry are preventable: An epidemiological study. Am J Respir Crit Care Med 1998;158:1499-503.

15. Gimenez C, Fouad K, Choudat D, Laureillard J, Bouscaillou P, Leib E. Chronic and acute respiratory effects among grain mill workers. Int Arch Occup Environ Health 1995;67:311-5.

16. Bohadana AB, Massin N, Wild P, Kolopp MN, Toamain JP. Respiratory symptoms and airway responsiveness in apparently healthy workers exposed to flour dust. Eur Respir J 1994;6:1070-6.

17. Wagh ND, Pachpande BG, Patel VS, Attarde SB, Ingle ST. The Influence of workplace environment on lung function of flour mill workers in Jalgaon Urban Center. J Occup Health 2006;48:396-401.

18. De Zotti R, Larese F, Bovenzi M, Negro C, Molinari S. Allergic airway disease in Italian bakers and pastry makers. Occup Environ Med 1994;51:548-52.

19. Gautrin D, Infante-Rivard C, Dao T, Magnan-Larose M, Desjardins D, Malo JL. Specific IgE dependent sensitization, atopy and bronchial hyperresponsiveness in apprentices starting exposure to protein-derived agents. Am J Respir Crit Care Med 1997;155:1841-7.

20. Smith TA, Patton J. Health surveillance in milling, baking and other food manufacturing operations - five years' experience. Occup Med 1999;49:147-53.

21. Smith TA, Parker G, Hussain T. Respiratory symptoms and wheat flour exposure: A study of flour millers. Occup Med 2000;50:25-9.

22. De Zotti R, Bovenzi M. Prospective study of work related respiratory symptoms in trainee bakers. Occup Environ Med 2000;57:58-61.

23. Karjalainen A, Kurppa K, Virtanen S. Incidence of occupational asthma by occupation and industry in Finland. Am J Ind Med 2000;37:451-8.

24. Choudat D, Fabriès JF, Martin JC. Bronchial challenge with flour: early response is dependent on the dose of activated allergen inhaled. Eur Respir J 2002;20:409-16.

25. Brisman J. Baker's asthma. Occup Environ Med 2002;59: 498-502.

26. Bulat P, Myny K, Braeckman L. Exposure to inhalable dust, wheat flour and a-amylase allergens in industrial and traditional bakeries. Ann Occup Hyg 2004;48:57-63.

27. Shamssain MH. Respiratory symptoms and pulmonary function in flour processing workers in the baking industry. Am J Ind Med 1995;27:359-65.

28. Chen P. The effect of grain dust on non-specific bronchial hyper reactivity. Zhonghua Jie He He Hu Xi Za Zhi 1992;15: 28-30.

This work is available in Open Access model and licensed under a Creative Commons Attribution-NonCommercial 3.0 Poland License - http://creativecommons.org/ licenses/by-nc/3.0/pl/deed.en. 